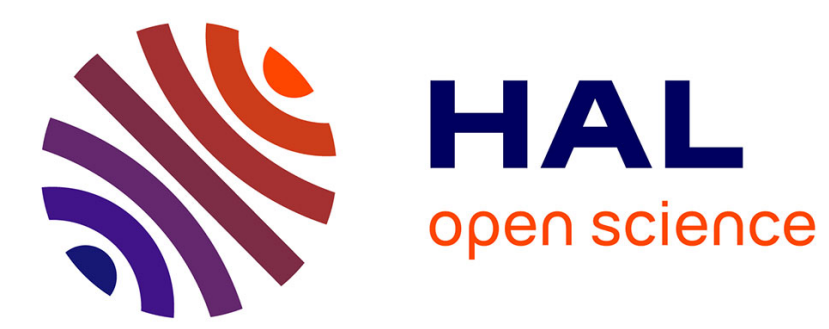

\title{
EFFECTS OF SHOCK PRESTRAIN ON THE DYNAMIC MECHANICAL BEHAVIOR OF TANTALUM
}

D. Lassila, G. Gray

\section{- To cite this version:}

D. Lassila, G. Gray. EFFECTS OF SHOCK PRESTRAIN ON THE DYNAMIC MECHANICAL BEHAVIOR OF TANTALUM. Journal de Physique IV Proceedings, 1991, 01 (C3), pp.C3-19-C3-26. 10.1051/jp4:1991303 . jpa-00249894

\section{HAL Id: jpa-00249894 https://hal.science/jpa-00249894}

Submitted on 1 Jan 1991

HAL is a multi-disciplinary open access archive for the deposit and dissemination of scientific research documents, whether they are published or not. The documents may come from teaching and research institutions in France or abroad, or from public or private research centers.
L'archive ouverte pluridisciplinaire HAL, est destinée au dépôt et à la diffusion de documents scientifiques de niveau recherche, publiés ou non, émanant des établissements d'enseignement et de recherche français ou étrangers, des laboratoires publics ou privés. 
Colloque C3, suppl, au Journal de Physique III, Vol. 1, octobre 1991

\title{
EFFECTS OF SHOCK PRESTRAIN ON THE DYNAMIC MECHANICAL BEHAVIOR OF TANTALUM
}

\author{
D.H. LASSILA* and G.T. GRAY III** \\ "University of California, Lawrence Livermore National \\ Laboratory, Livermore, CA 94550, U.S.A. \\ * University of California, Los Alamos National Laboratory, Los \\ Alamos, NM 97545, U.S.A.
}

Résumé: Les effets de la prédéformation d'un choc sur le comportement mécanique et la microstructure du tantale recuit ont été examinés. Le matériau testé a subi un choc de $15 \mathrm{GPa}$ pendant $1 \mu \mathrm{s}$ et a été récupéré sans endommagement de telle sorte que la déformation produite durant l'expérience soit dû essentiellement au chargement par choc. Une caractérisation mécanique des matériaux recuits et récupérés après choc a été effectuée en traction et en compression dans un domaine de vitesse de déformation très important $\left(10^{-3}\right.$ à $\left.7000 \mathrm{~s}^{-1}\right)$. L'écrouissage par choc entraîne une augmentation de la limite élastique quasi-statique du tantale, mais elle n'a pratiquenent aucune influence sur la réponse dynamique en contrainte-déformation. En accord avec ces résultats, le comportement an traction des deux matériaux recuits et récupérés après choc sont pratiquement identiques. Les effets de l'écrouissage par choc sur ia microstructure du matériau testé ont été examinéspar microscopie optique et micrescopie électronique à transmission. On discute les résultats de ces essais et leur corrélation avec les effets de la prédéformation par choc sur le comportement mécanique.

\begin{abstract}
The effects of shock prestrain on the mechanical behavior, microstructure, and substructure of annealed tantalum have been examined. The test material was shocked to $15 \mathrm{GPa}$ for $1 \mu \mathrm{s}$ and soft-recovered such that deformation that occurred during this procedure was predominantly due to the shock loading. Mechanical characterization of the annealed and shock-recovered tantalum was performed over a wide range of strain rates $\left(10^{-3}\right.$ to $\left.7000 \mathrm{~s}^{-1}\right)$ in both tension and compression. Shock prestraining caused an increase in the quasi-static yield strength of tantalum but had virtually no influence on the dynamic stress-strain response. Consistent with this, the dynamic tensile behavior of both the annealed and shock-recovered materials were nearly identical. The effects of shock prestrain on the microstructure and substructure of the test material was examined using optical and transmission electron microscopy. The results of these examinations and how they correlate with the effects of shock prestrain on mechanical behavior are discussed.
\end{abstract}

\section{Introduction}

Among the extensive number of structure/property studies on shock-loading effects in metals, metals and alloys with an FCC crystal structure have been the focus of the majority of the investigations [13]. In contrast, $\mathrm{BCC}$ metals have been less extensively studied with iron, molybdenum, and recently niobium [3] receiving the most attention. To the best of our knowledge, neither the residual microstructures or mechanical response of shock-loaded tantalum have been reported. In addition, none of the previous shock studies probing the post-shock mechanical behavior of BCC metals have

* Work performed under the auspices of the U. S. Department of Energy by the Lawrence Livermore National Laboratory under contract No. W-7405-ENG-48. 
investigated the dynamic reloading response but rather concentrated on the post-shock quasi-static or hardness properties. To assess the dynamic mechanical response of shock-prestrained tantalum we have shock loaded polycrystalline $99.98 \% \mathrm{Ta}$ to $15 \mathrm{GPa}$, "soft" recovered the samples, and then sectioned the recovered discs for quasi-static and dynamic mechanical testing and transmission electron microscopy (TEM) examination.

\section{Experimental}

The starting material for the study was rolled and annealed vacuum arc-remelted (VAR) tantalum plate, which was $99.98 \%$ pure (the chemical analysis is reported in Table 1). Optical metallography revealed a starting microstructure consisting of equiaxed grains with a nominal diameter of $60 \mathrm{~mm}$ with some banding of large grain regions $(100 \mu \mathrm{m}$ diameter).

Shock-recovery experiments were performed using an 80-mm single-stage-gas gun [4]. The specimen assembly consisted of a 5.08-mm-thick, 38-mm-diameter sample, sandwiched behind a 38-mm-diameter, 2.54-mm-thick cover plate. Both components were tightly fitted into a bored

Table 1. Chemical analysis of the test material (weight percent in PPM).

\begin{tabular}{|c|c|c|c|c|c|c|c|c|c|c|c|c|c|c|}
\hline $\mathrm{O}$ & $\mathrm{N}$ & $\mathrm{C}$ & $\mathrm{H}$ & $\mathrm{Fe}$ & $\mathrm{Ni}$ & $\mathrm{Cr}$ & $\mathrm{Ca}$ & $\mathrm{Cu}$ & $\mathrm{Si}$ & $\mathrm{Ti}$ & $\mathrm{Mo}$ & $\mathrm{W}$ & $\mathrm{Nb}$ & $\mathrm{Ta}$ \\
\hline 38 & 24 & 5 & $<1$ & 27 & 39 & 18 & $<2$ & $<1$ & $<8$ & $<5$ & $<5$ & $<40$ & $<10$ & $\mathrm{Bal}$ \\
\hline
\end{tabular}

recess of a $7^{\circ}$-tapered, $12.7-\mathrm{mm}$-thick, central momentum disk. The sample was protected from spallation by backing the central momentum disk with a 3.8-mm-thick spall plate. The central disk and spall plate were further surrounded by two concentric momentum-trapping rings with outside diameters of 69.8 and $82.5 \mathrm{~mm}$. The central momentum disk, outer momentum-trapping rings, and spall plate were fabricated from Ta-2W to help ensure "soft" recovery. Tantalum samples were shock loaded to $15 \mathrm{GPa}$ by impacting the specimen assembly with a 1.9 -mm-thick flyer plate at a velocity of $486 \mathrm{~m} / \mathrm{sec}$. Soft recovery and simultaneous cooling are achieved by decelerating the central momentum disk in a water catch chamber positioned immediately behind the impact area. Utilization of these techniques yielded samples with a residual strain of $<2 \%$.

Compression test samples were electrodischarge machined (EDM) from the shock-recovered disk from locations shown in Figure 1. The compression samples measured $5.0 \mathrm{~mm}$ in length and $5.0 \mathrm{~mm}$ in diameter. Testing performed at strain rates less than $100 \mathrm{~s}^{-1}$ were performed using screw-driven or servo-hydraulic test machines, in which case the strain measurement was made using an extensometer attached to the compression platens. Dynamic compression tests at strain rates of approximately $4000 \mathrm{~s}^{-1}$ were performed using the split Hopkinson pressure bar (SHPB) technique. For SHPB testing at strain rates greater than $4000 \mathrm{~s}^{-1}$ compression samples with a $2.5 \mathrm{~mm}$ length and $2.5 \mathrm{~mm}$ in diameter were used.

Tensile tests were performed at strain rates of $10^{-3} \mathrm{~s}^{-1}$ and approximated $5000 \mathrm{~s}^{-1}$ using sheet tensile samples with a gage section $5.0 \mathrm{~mm}$ long, $1.0 \mathrm{~mm}$ thick, and $2.0 \mathrm{~mm}$ wide. Low strain rate tests were performed using a screw-driven test machine, in which case the strain measurement was made by an extensometer attached directly to the gage section of the test sample. The dynamic tensile tests were performed using the SHPB technique, the details of which are reported elsewhere [5].

Transmission electron microscopy (TEM) was used to investigate the substructures of the shocked and unshocked materials. Disks 3 -mm in diameter were punched from mechanically thinned sheet and electropolished at a potential of 4 volts in a solution of $3.8 \% \mathrm{H}_{2} \mathrm{SO}_{4}, 0.8 \%$ $\mathrm{HF}, 22 \% 2$-Butoxethanol, and $73 \%$ methanol at $-50^{\circ} \mathrm{C}$. Observation of the foils was performed using a JEOL $2000 \mathrm{EX}$ microscope operated at an electron beam accelerating voltage of $200 \mathrm{kV}$. 


\section{Results}

\section{Compression Testing}

Compression testing of the shocked and unshocked material was performed over a range of strain rates from $1.6 \times 10^{-5} \mathrm{~s}^{-1}$ to $5000 \mathrm{~s}^{-1}$ (figure 2). At the slow strain rates the shocked material exhibited an increase in yield strength and a decrease in work-hardening rate similar to that of shock-loaded copper [6]. However, there appears to be a major difference in the subsequent work hardening of shocked $\mathrm{Ta}$ in comparison to $\mathrm{Cu}$, specifically the stress strain response of the shocked and unshocked materials converge at relatively low values of true strain $(20 \%)$, as shown in Figure 3. The strain at which convergence occurs decreases with increasing strain rate. At a strain rate of $4000 \mathrm{~s}^{-1}$ the stress strain response of the shocked and unshocked materials are virtually identical as shown in Figure 3 . The strain rate sensitivity of the flow stress

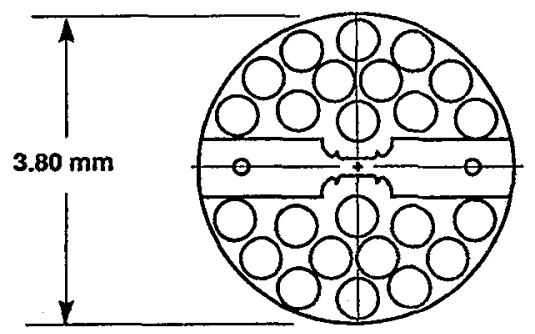

Figure 1. Diagram showing the positions the the test samples in the shocked disk.

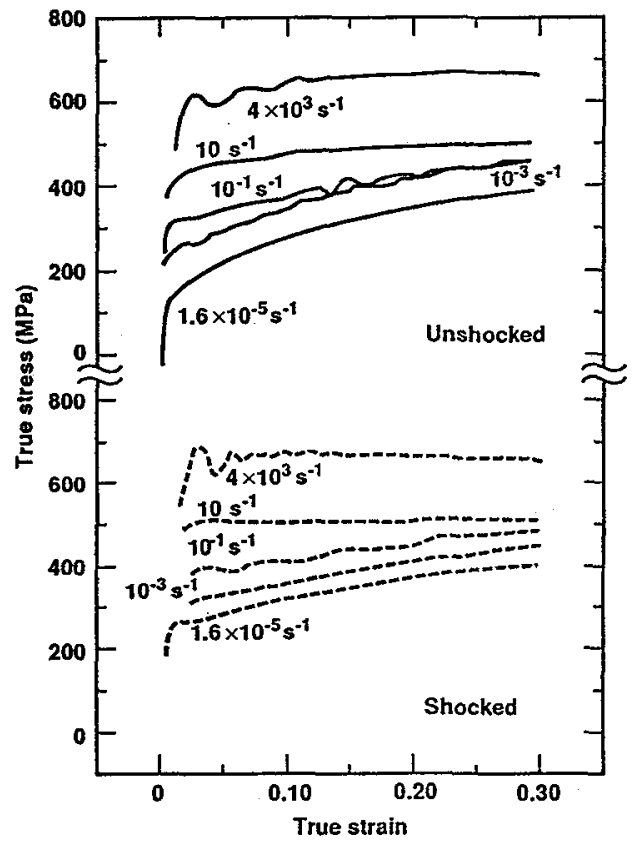

Figure 2. True-stress/true-strain curves of shocked and unshocked material. 


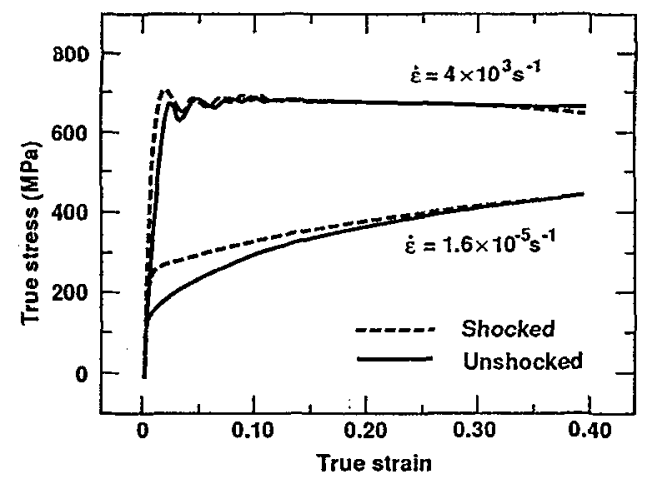

Figure 3. True-stress/true-strain behavior of shocked and unshocked material at quasi-static and dynamic strain rates.

at a true strain of $10 \%$ for the shocked and unshocked materials, shown in Figure 4, were found to be nearly identical at strain rates below $10 \mathrm{~s}^{-1}$ and consistent with that previously reported for annealed tantalum [7]. At strain rates above $10 \mathrm{~s}^{-1}$ the shock-prestrained material exhibits a decrease in strain rate sensitivity relative to the unshocked material.

Serrated yielding was observed in both the shocked and unshocked materials indicating dynamic strain-aging (Portenvin-LaChatelier effect) associated with interstitial impurities was occurring. This phenomenon was most pronounced in the shocked and unshocked materials at a strain rate of $10^{-2} \mathrm{~s}^{-1}$, as shown in Figure 5. The flow stress during serrated yielding often dropped far below the expected value of flow stress based on the plot of flow stress versus strain rate shown in Figure 4.

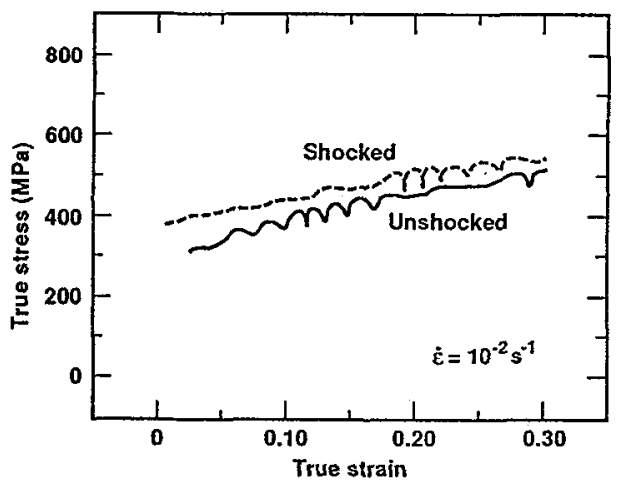

Figure 4. True-stress/true-strain behavior of shocked and unshocked material at a strain rate of $10^{-2} \mathrm{~s}^{-1}$ indicating dynamic strain aging.

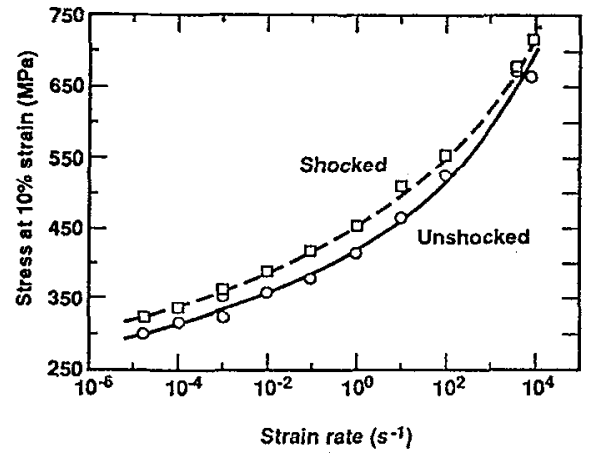

Figure 5. Plot of the strain rate sensitivities of the shocked and unshocked material. Some of the scatter in the data at strain rates of approximately $10^{-2} \mathrm{~s}^{-1}$ is due to the effects of dynamic strain aging. 


\section{Tensile Testing}

Results of the quasi-static and dynamic tension testing are shown in Figure 6 in the form of engineering stress-strain plots. The strain at which deformation instability (maximum load) occurred in the shocked material at the strain rate of $10^{-3} \mathrm{~s}^{-1}$ was significantly less than that of the unshocked material. This behavior may be accounted for by the decrease in work-hardening rate of the shocked material using the well-known Considére criterion. A relatively small upper yield was detected in tension at the strain rate of $10^{-3} \mathrm{~s}^{-1}$, where none was observed in compression. This is most likely due to the more precise load and strain measurements that were employed in the slow rate tension tests.

Under dynamic tensile loading the behavior of the shocked and unshocked materials is nearly identical. The strain at which necking begins under dynamic loading was determined visually by using a framing camera record of the test. The test results indicated that necking occurred in the shocked and unshocked materials at nearly the same point on the stress-strain record. Overall, the results of the dynamic tensile tests are consistent with the high strain rate compression test, which showed the shocked and unshocked materials to have similar constitutive behavior under dynamic loading.

\section{TEM and Metallography}

Metallographic examination of the unshocked material revealed an equiaxed grain structure as shown in the optical light micrograph in Figure 7-a. Shock loading produced deformation twins in many but not all of the grains (Figure 7-b). Observations of the substructure of the unshocked material made using TEM revealed a random distribution of dislocations and a dislocation density relatively high for an annealed material (Figure 8-a). This observation is however similar to that previously noted in annealed tantalum [8]. The dislocation substructure in the shock-loaded tantalum is observed to consist of a low density of random tangled dislocation networks and a high density of straight screw dislocations interspersed with dislocation loops (Figure 8-b). Evidence of deformation twinning in the shocked material using TEM was not found, probably due to an insufficient number of foils examined. TEM observations of the shocked and unshocked material that had been deformed quasi-statically to a true strain of $35 \%$ indicated the substructures of the materials to be similar with dense areas of dislocation networks forming cell walls.

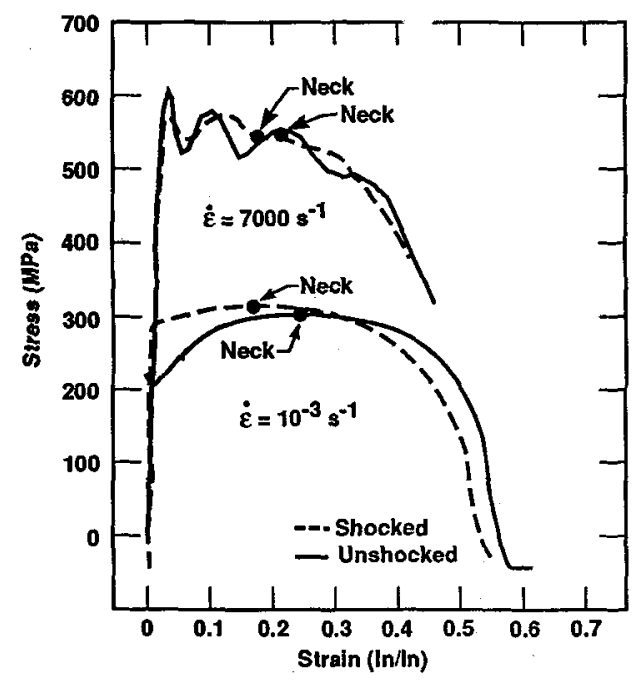

Figure 6. Engineering stress/strain behavior of the shocked and unshocked materials under quasistatic and dynamic tensile loading. 
(a)

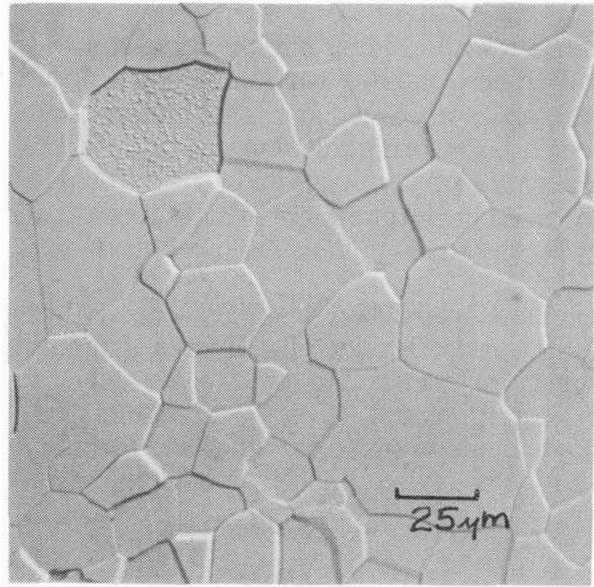

(b)

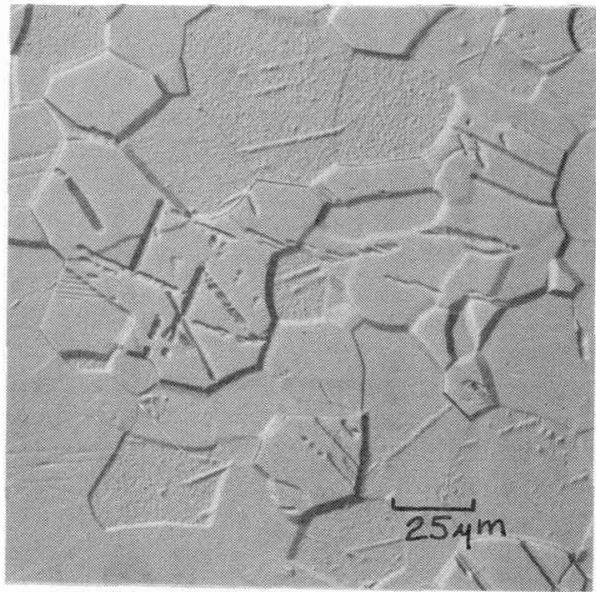

Figure 7. a) Light micrograph of the annealed starting material. b) Light micrograph of shock prestrained material indicating significant amounts of deformation twinning.

(a)

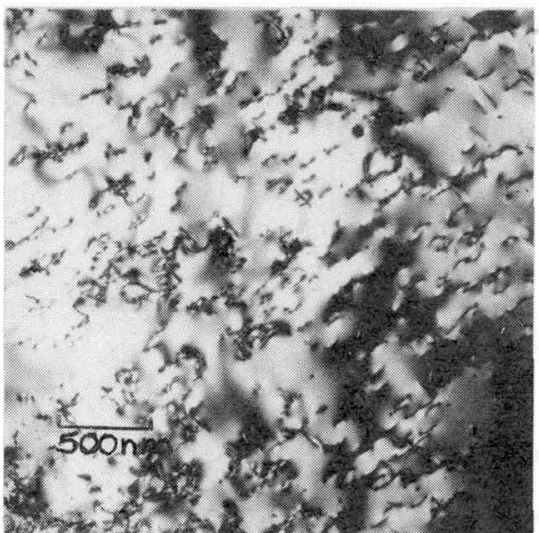

(b)

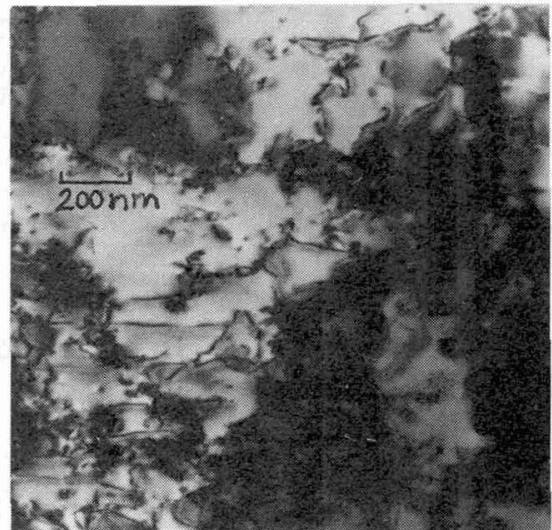

Figure 8. a) TEM micrograph of the annealed starting material indicating a relatively high dislocation density for an annealed material. b) TEM micrograph of shock prestrained material showing a large fraction of long straight screw dislocations. 


\section{Discussion}

Shock prestraining is seen to increase the quasi-static yield strength of tantalum but have virtually no influence on the dynamic stress-strain response. The total transient strain, calculated as $4 / 3\left(\ln \left(\mathrm{V} / \mathrm{V}_{0}\right)\right)$ where $\mathrm{V}_{0}$ and $\mathrm{V}$ are the initial and shock volumes, in the $15 \mathrm{GPa}$ shock in tantalum is equal to 0.091 . Shifting of the quasi-static reload shock-prestrained stress-strair. curve by $9.1 \%$ strain to make a comparison, on an equivalent strain basis, with the annealed curve shows that no net shock hardening above the low-rate strain response has occurred. In addition, tantalum is observed to work-harden when deformed quasi-statically but not dynamically, independent of whether it is annealed or shock-prestrained.

The post-shock mechanical response of tantalum is thought to be heavily influenced by the defect storage behavior under dynamic-loading conditions. In this work, shock prestraining of tantalum resulted in a high density of straight screw dislocations and some deformation twins. Both of these microstructural and substructural features can occur under quasi-static loading at low temperatures and may be a consequence of the activation energies associated with the mobilities of edge and screw dislocations. Under low temperature and/or high strain-rate loading conditions, the local stresses necessary for dislocation motion (dislocation-dislocation interactions, cross slip, etc.) are increased due to the suppression of thermal activation. At some point during shock loading at $15 \mathrm{GPa}$ the flow stresses in our test material became sufficiently high due to the lack of thermal activation that the twinning threshold stress was exceeded in many, but not all of the grains. The reason for the unusual substructure of the shocked material (long straight screws) may be that in BCC metals, edge dislocations can move through the lattice at relatively low stresses, while screw dislocation motion requires considerably higher stress levels due to high Peierls barriers [9] under deformation conditions which are not assisted by thermal activation. Thus, screw dislocations will remain in the lattice while edges are swept out.

The low dislocation density and dislocation character (long straight screws) of the shocked material is consistent with the moderate degree of hardening that the shock produced. Straight screw dislocations, i.e. lineal glide, will not result in any storage of dislocations because dislocation generation is essentially not possible [10]. To store edge dislocations under these conditions requires some additional mechanisms to lock the structure in place and cause hardening [10]. Without significant screw dislocation generation and storage, i.e. areal glide, work-hardening will be severely limited or nonexistent, consistent with the results presented in this work and previous low temperature studies. Alloying additions to tantalum, either interstitial or substitutional, is expected to increase the amount of secondary slip and dislocation storage, in particular the edges, which in turn is expected to increase shock-hardening.

The lack of work-hardening of tantalum, both in the shocked and unshocked conditions is not well understood but may be related to the strong temperature dependence of Stage II workhardening of BCC materials $[11,12]$. For pure tantalum, the rate of Stage II hardening rapidly decreases below approximately $450 \mathrm{~K}$ such that at $300 \mathrm{~K}$ Stage II does not exist [11]. In addition, deformation at low temperatures was seen to suppress secondary slip [11]. Stress-strain results on tantalum at $194 \mathrm{~K}$ show that the slope of the stress-strain curve is approximately zero. The current results on dynamically deformed shocked and unshocked tantalum exhibit trends similar to the low temperature literature studies. This suggests the thermally activated processes that control work-hardening at low test temperatures under quasi-static loading also control workhardening under dynamic loading. Additional experiments, already in progress, are required to examine in more detail the correlation between substructure evolution and the lack of workhardening in tantalum.

\section{Acknowledgments}

The mechanical testing was performed by M. M. LeBlanc and J. Thournir and is gratefully acknowledged. The authors would also like to thank R. Kershaw and I. Del Rio for the metallographic analyses and $\mathrm{C}$. Trujillo for performing the shock recovery experiments. The authors wish to acknowledge helpful discussions and suggestions of U. F. Kocks and J. D. Embury. This work was supported by the Joint DoD/DOE Munitions Development Program under the auspices of the U.S. Department of Energy by the Lawrence Livermore National Laboratory under Contract No. W-7405-Eng-48. 


\section{References}

1. W. C. Leslie, in "Metallurgical Effects at High Strain Rates", Plenum Press, R. W. Rhode, et al. (eds.) New York, 1973, p571.

2. L. E. Murr, in "Shock Waves and High Strain Rate Phenomena in Metals", M. A. Meyers and L. E. Murr (eds.) Plenum Press, New York, 1981, p607.

3. J. C. Huang and G. T. Gray III, Mat. Sci. and Eng., A103, 1988, p241.

4. G.T. Gray III, P.S. Follansbee, and C.E. Frantz, Mat. Sci. Eng. A111 (1989) p9.

5. M. LeBlanc and D. H. Lassila, UCRL in preparation, Univ. of California, Lawrence Livermore National Laboratory, 1991.

6. D. H. Lassila and G. T. Gray III, in "International Conference on High Strain Rate Phenomena in Materials", M. A. Meyers et al. (eds.), San Diego, CA, August 1990 (in press).

7. K. E. Hoge and A. K. Mukherjee, J. of Mat. Sci., 12, 1977, p1666.

8. D. Hull, I.D. McIvor, and W.S. Owens, J. Less-Common Metals 4 (1962) 409.

9. J.A. Shields, R. Gibala, and T.E. Mitchell, Metall. Trans. 7A (1976) 1111.

10. U.F. Kocks, in The Mechanics of Dislocations, Amer. Soc. Metals, Metals Park, Ohio (1985) 81.

11. R.J. Arsenault, and A. Lawley, in Work Hardening, Gordon and Breach, NY 1968), p. 283.

12. T.E. Mitchell, and W.A. Spitzig, in Refractory Metals and Alloys IV, Gordon and Breach, NY (1967) p. 25. 